\title{
INSULAR SOURCES AND ANALOGUES OF THE OTHERWORLD IN THE MIDDLE ENGLISH SIR ORFEO
}

\author{
Jordi Sánchez Martí
}

Universidad de Alicante

\begin{abstract}
The Middle English romance Sir Orfeo presents a medievalized version of the classical myth of Orpheus that shows the influence of Celtic lore. Modern scholars seem to have accepted the views of A. J. Bliss, the editor of this Middle English poem, who argues that the English text is a translation of an AngloNorman or Old French version. Since we have no textual evidence that can positively support Bliss's hypothesis, this article tests the possibility that the Middle English romance actually represents an insular tradition of the Orpheus myth that originated in Anglo-Saxon times with King Alfred's rendering of the story and continued evolving by means of oral-memorial transmission until the fourteenth century, when the English romance was written down in the Auchinleck manuscript.
\end{abstract}

Keywords: Sir Orfeo, King Alfred, Otherworld, Walter Map, Marie de France, Geoffrey of Monmouth.

\section{Resumen}

El romance de Sir Orfeo presenta una versión medievalizada del relato clásico de Orfeo con fuertes influencias de origen celta. Sin embargo, la crítica parece que ha dado por bueno el criterio de A. J. Bliss, editor del texto en inglés medio, quien considera que la versión inglesa debe de ser una traducción de un original anglonormando o francés. Dado que no existen testimonios textuales directos que confirmen la hipótesis de Bliss, este artículo explora la posibilidad de que el romance medieval sea el resultado de una versión inglesa que se originó en tiempos anglosajones con la versión del rey Alfredo y que siguió evolucionando por medio de su transmisión oral hasta el siglo XIV, cuando se compone el romance in inglés medio.

Palabras clave: Orfeo, rey Alfredo, ultramundo, Walter Map, Marie de France [María de Francia], Geoffrey of Monmouth. 
The first half of the fourteenth century saw a flourishing of the genre of the Breton lays in English, as the production of Lai le Freine (NIMEV 3869) ${ }^{1}$, Sir Landeval (NIMEV 3203), Sir Orfeo (NIMEV 3868), and Sir Degare (NIMEV 1895) well attests (Marvin 865). This literary form did not originate in Britain, but in Brittany, as explained by Marie de France in the opening lines of her lay Equitan:

Mut unt esté noble barun

Cil de Bretaine, li Bretun.

Jadis suleient par prüesce,

Par curteisie e par noblesce

Des aventures que oiëent,

$\mathrm{Ki}$ a plusur gent aveneient,

Fere les lais pur remembrance,

Que [hum] nes meïst en ubliance. (lines 1-8)

[The Bretons, who lived in Brittany, were fine and noble people. In days gone by these valiant, courtly and noble men composed lays for posterity and thus preserved them from oblivion; trans. Burgess and Busby 56]

Although none of the lays that would have been originally composed by the Breton jongleurs has come down to us, there is scholarly consensus that they served as model and inspiration to Marie, who put them into circulation in England in the second half of the twelfth century, during the reign of Henry II (Hunt 666). From that moment onwards the genre was cultivated in England, though primarily not in English but in Anglo-Norman. Perhaps the best proof of the genre's insular popularity comes from a list containing over sixty titles of lays, romances and other kinds of narrative works that is preserved in Shrewsbury School, MS 7, a manuscript produced in England in the midthirteenth century. ${ }^{2}$ It seems reasonable to assume that the texts included in that list were widely disseminated in thirteenth-century England, even if they were written or composed in Anglo-Norman.

This essay focuses on one of the earliest Breton lays to be composed in English, Sir Orfeo, which presents a medievalized version of the classical myth of Orpheus, more generally known to us from the Latin renderings of Ovid,

\footnotetext{
' NIMEV refers to Julia Boffey and A. S. G. Edwards. A New Index of Middle English Verse. London: The British Library, 2005.

${ }^{2}$ The list appears on fol. 200r. A transcription and facsimile reproduction is provided by Archibald (60-61). Although the manuscript is dated to the mid-thirteenth century, item 5(a), containing the list, was added after 1270 (Ker and Piper 4: 296-97); cf. Brereton.
} 
Virgil, and Boethius. ${ }^{3}$ The classical element of the Middle English work together with its artistic quality endows it with a distinctive literary flavour to the extent that, as Bennett has stated, "Of all the English verse romances, Sir Orfeo is the one that in grace and charm, lightness and neatness, comes closest to the twelfthcentury lays of Marie de France" (138). The anonymous English poet made a conscious effort to imitate the generic model provided by Marie and imposed the same generic label on his text when presenting it as one of "pis layes" that "In Breteyne ... were wrouzt" (13; these lays that were composed in Brittany). ${ }^{4}$ Such a statement could convey the impression that this narrative originated in Brittany and circulated in Old French and/or Anglo-Norman, just like the works listed in the Shrewsbury School manuscript. In fact, a number of texts of French origin contain references to a Breton lai d'Orphey that have led scholars to suggest that it must have been the source used by the English poet (Bliss xxxi-xxxiii). Kittredge $(181,201-02)$ argues that Sir Orfeo is the translation of an Old French version, which modified the classical account of Orpheus with the use of Celtic elements that an Armorican jongleur could have adopted from the fifth-century Irish legend The Wooing of Etain. ${ }^{5}$ Bliss, however, considers that the points of resemblance between The Wooing of Etain and Sir Orfeo might be due to coincidence and concludes, "Sir Orfeo was translated from an O[1d] F[rench] or A[nglo-] N[orman] narrative lai based on the conte accompanying a Breton lai of Orpheus"' (xli). More recently, from references in the Scottish ballad King Orpheus, Marie-Thérèse Brouland has also proposed the existence of a musical lai d'Orfée of Celtic origin, but states, "le lai celtique au nom d'Orphey chanté par les Irois n'est pas forcément le lai anglo-normand, ni l'œuvre moy. anglaise que nous possédons" (43). But all these theories face the same major obstacle, namely, that no text of either the Old French or the Celtic lay of Orpheus has survived. Moreover, the medieval allusions to an earlier French version lack the sufficient specificity to surmise that such a version, even if it existed, gave the same narrative treatment of the Orpheus story as shown in the Middle English work. As A. C. Spearing notes, "the processes by which it [i.e. the classical myth of Orpheus] has been so strangely transformed [in Sir Orfeo] remain uncertain, partly because no immediate source has been found for the English poem" (260).

\footnotetext{
${ }^{3}$ See Ovid (Metamorphoses, X.1-85, XI.1-84), Virgil (Georgics, IV.453-527), and Boethius (Consolatio Philosophiae, III, metre 12).

${ }^{4}$ Unless otherwise stated, all quotations from Sir Orfeo refer to the version in the Auchinleck manuscript (National Library of Scotland, Adv. MS. 19.2.1) as edited by Bliss, and all translations are my own, unless otherwise noticed. For the problems relating to the prologue of the Auchinleck version, see Bliss (xlvii-viii).

${ }^{5}$ Smithers (86) also argues that The Wooing of Etain is a source of Sir Orfeo and not only an analogue. Cf. Loomis 302-03.
} 
There is one further consideration to be made: despite the extensive list of works contained in the Shrewsbury School manuscript, it is telling that no Anglo-Norman lay of Orpheus is mentioned (Archibald 62). In other words, if such a text did exist, it had little or no relevant circulation in thirteenth-century England and, therefore, it cannot be assumed that it would have been easily accessible to the Middle English author of Sir Orfeo. Instead, he must have composed his text independently from a hypothetical Anglo-Norman lay of Orpheus. Alternatively, if the Sir Orfeo author was acquainted with the now lost Old French lai d'Orphey mentioned in other contemporary works, should we consider the Middle English text as a translation, as Bliss and Kittredge seem to argue? In that case we should understand that the motifs specific to the Middle English version derive from the Old French original. By contrast, if evidence can be provided that those motifs could have been transmitted to the English poet through alternative means, it could then be argued that the Middle English version represents an insular tradition unconnected with and parallel to the French one. This essay proposes to explore and identify precisely if such alternative means of transmission existed and could have informed the creative efforts of the Sir Orfeo poet. In particular I have centred my attention on the otherworldly features in the Middle English romance, mostly of Celtic derivation, and traced their presence in English works that were produced before or contemporaneously with the Middle English text. ${ }^{6}$ To do so, I search some of the Celtic sources for those motifs and then examine relevant English instantiations of the same narrative patterns. My goal is to assess to what extent the narrative components of the Middle English Sir Orfeo discussed in this article formed an integral part of the English literary and cultural landscape and could have been borrowed by the English poet for his own literary purposes without resorting to a continental source as hypothetically represented by the Old French lay d'Orphey.

The action of Sir Orfeo starts when Heurodis "in an vndrentide ... Vnder a fair ympe-tre, ... Fel on slep opon pe grene" (lines 65, 70, 72; In mid-morning, under a pleasant grafted tree, [she] fell asleep on the grass), containing three elements that produce the perfect setting for some momentous event to take place. First, the vndrentide, referring to midday, ${ }^{7}$ the time of day when

\footnotetext{
- By English works I describe texts that were produced in England in all the languages that were in use there in the Middle Ages, including Anglo-Norman, Latin, Old English, Old French, and Middle English. The fragments from the Old Scots romance of King Orphius are not central to this discussion, not because this text was produced in Scotland (and not in England), but mainly because it is derived from the Middle English Sir Orfeo through oral transmission and composed around the third quarter of the fifteenth century (Purdie 23-33).

For a discussion of the meaning of the word vndrentide in the context of our poem, see Jirsa (141-42, n. 3).
} 
supernatural incidents were more likely to occur according to the medieval imagination (Friedman 188-90). Second, the ympe-tre or "grafted tree" may be understood as a manifestation of a magic tree from Celtic lore (Patch, Otherworld 52-53), although there was also a tradition, going back to Pliny's Naturalis historia and touched on by Bartholomaeus Anglicus (d. 1272) in his De rerum proprietatibus (ca. 1245), ${ }^{8}$ suggesting that the shadow cast by certain types of trees could have a "disruptive influence over the regular course of the natural world" (Jirsa 146). Even though no specific or special property can be attributed to grafted trees, it seems reasonable that their shadow could increase the potency of certain unearthly phenomena, since the man-made process of grafting combines the sap of two types of trees and, in a way, results in the creation of a tree through unnatural means. Third, the slumber into which Heurodis falls seems to put her in a state of suspended animation that diminishes her sensory powers, thus making her more susceptible to physical assault from supernatural agents. The magic-inducing power of a state of somnolence was used as a motif in the Celtic literary tradition and can be seen already in the seventh-century The Voyage of Bran Son of Febal, where Bran falls asleep listening to music: "When he awoke from his sleep, he saw close by him a branch of silver with blossoms" (2), i.e. a magic tree. ${ }^{9}$ The heroes in The Voyage of Mael Duin (8th-9th c.) also fall asleep and next find themselves transported to an entirely different reality: "When they awoke, they were in their boat on a crag, and they saw not the island, nor the fortress, nor the lady, nor the place wherein they had been" (493). Finally, the tenth-century The Wasting Sickness of Cú Chulainn describes how Cú Chulainn "put his back against a rock, and he was downcast; and he fell asleep" (31), prompting the appearance of two women.

Thomas Chestre's Sir Launfal (NIMEV 567), derived from Marie de France's Lanval, provides a close parallel with the situation of Heurodis in Sir Orfeo:

The wether was hot the underntyde;

Thus sat the knyght yn symplyte,

In the schadwe unther a tre,

Ther that hym lykede best.

As he sat yn sorow and sore,

\footnotetext{
" See Seymour for biographical information.

- All Irish texts are quoted in English translation only, and the translators are mentioned in the list of works cited at the end of the article.
} 
He saw come out of holtes hore

Gentyll maydenes two. (lines 220, 226-31)

[The weather was hot that morning. The knight sat thus without ostentation under the shadow of a tree, where he liked best. While he sat in sorrow and grief, he saw two gentle maidens come out of the hoar woods.]

In the case of Launfal, both the time of day (underntyde) and his location in the shadow of a tree (In the schadwe unther a tre) suffice to trigger the otherworldly apparition. These two details were not in Marie de France's Lanval, but were introduced by Chestre, probably because they were perceived as already belonging to the insular tradition and were hence easily recognizable to English audiences for their premonitory value. ${ }^{10}$ There is no need for Launfal to enter into a state of drowsiness for the supernatural beings to materialize, since the presence of only two of the three conditions mentioned above is enough for the unearthly events to take place, as confirmed in Sir Orfeo: "Rizt as pai slepe her vnder-tides / Eche was pus in pis warld y-nome, / Wip fairi pider y-come" (402-04; Just as they took their midday nap, each one was thus in this world taken, and come thither with enchantment).

The concurrence of the three conditions in Sir Orfeo automatically causes the first intervention of otherworldly agents: "to fair kniztes" (135; two pleasant knights) command Heurodis to follow them to the presence of their lord. Since she refuses to do so, the Fairy King with some of his knights and ladies presents himself before Heurodis and takes her to his palace. Through Heurodis's eyes we have the first vision of the otherworld as she describes it to Orfeo: "\& schwed me castels \& tours, / Riuers, forestes, frip wip flours, / \& his riche stedes ichon" (159-61; And showed me castles and towers, rivers, forests, woodland with flowers, and each one of his splendid estates). When later on Orfeo enters fairyland himself, he gives a more detailed description (351-78) highlighting the richness of the materials used - crystal, gold, precious stones, enamel, etc. - and the impressive radiance of the place. This conception of the castle or palace of the otherworld as an ostentatious and fulgent edifice is reminiscent of descriptions of other similar buildings in Irish literature. The external view that Orfeo has of the castle ("Amidde pe lond a castel he size, / Riche \& real \& wonder heize," 355-56; In the middle of the land he saw a castle that was splendid, glorious and extremely high) is paralleled in The Adventure of Cian's Son Teigue, where Teigue asks, "what is this regal and great fortalice upon the

\footnotetext{
"For the relation between Chestre's and Marie's texts, see Stokes. For biographical information on Chestre, see Gray.
} 
high hill's face...?" (2: 390). The use of glass in the construction of the fairy palace (357-58) is well attested in medieval literature too. ${ }^{11}$ With regards to the pillars ("Pe werst piler on to biholde / Was al of burnist gold," 367-68; The worst pillar to look at was made all of polished gold), they are analogous to other similar structures in Celtic stories: the otherworld in The Wasting Sickness of Cú Chulainn includes "pillars of silver and glass" (39), and the protagonists of The Voyage of the Húi Corra (11th c.) talk of "a thing more wondrous than aught else, namely, a great pillar, silvern and fourcornered" (45). Finally, the brightness in Sir Orfeo's otherworld is described in the following terms:

Al pat lond was euer lizt,

For when it schuld be perk $\&$ nizt

pe riche stones lizt gonne

As brizt as dop at none pe sonne. (lines 369-72)

[All that land was always bright, since when it should be darkness and night, the precious stones shone as bright as does the sun at noon.]

This place's extraordinary effulgence is closely matched by the "bright radiant mansion" of The Adventure of Cian's Son Teigue, where "gems of crystal and of carbuncle in patterns were set in the wall of finndruine, in such wise that with flashing of those precious stones day and night alike shone" (393).

Despite the evident similarity among these descriptions of the otherworld, we need to bear in mind that, as Brouland remarks, "ces descriptions émerveillées ... finirent par perdre leur valeur metaphorique première pour devenir de simples locutions communes" (207). For instance, Marie de France depicts an otherwordly city in her Yonec using similar terms: "N'i ot mesun, sale ne tur, / Que ne parust tute d'argent" (362-63; "there was not a house, hall or tower which did not seem to be made of solid silver," trans. Burgess and Busby 90). In the fourteenth-century Sir Gawain and the Green Knight (NIMEV 3144), the appearance of the castle of Bertilak — who himself is "an alvisch man" (681; an elvish man) - is evoked using what can be considered as familiar elements of fantasy: "A castel the comlokest that ever knight aghte" (767; the finest castle that a knight ever owned), which also gleams considerably, "As hit schemered and schon thurgh the schyre okes" (772; as it glittered and shone through the bright oak trees). ${ }^{12}$ The use of lavish materials in combination with the brightness of the place, as we see in Sir Orfeo, also informs the Gawain-poet's description of the heavenly city in the dreamer's vision in Pearl (NIMEV 2744):

\footnotetext{
For a list of descriptions of the otherworld in which crystal is present, see Patch ("Descriptions of the Otherworld," 610 n. 3).

Cf. Putter and Stokes 665 n. to line 772.
} 
The stretes of gold as glasse all bare,

The wal of jasper that glent as glayre;

The wones withinne enurned ware

With all kynnes perre that myght repayre. (lines 1025-28). ${ }^{13}$

[The streets were made of gold as clear as glass, the city wall of jasper that glittered like the white of an uncooked egg; the dwelling places inside were bestudded with all the different sorts of precious stones that could be assembled.]

In addition, the fairyland of Sir Orfeo presents a topographical feature, namely, that it is "Smope \& plain \& al grene" (353; smooth and flat and entirely green), on which Ben Weber has recently shed some light. He has reconstructed the exegetical tradition that informs this landscape element and shown that it is based on a biblical allusion:

Omnis vallis exaltabitur, et omnis mons et collis humiliabitur; et erunt prava in directa, et aspera in vias planas. (Isa. 40.4)

[Every valley will be raised, and every mountain and hill will be made low, and the crooked will be made straight, and the rough places will be turned into flat ways.]

Weber has explained how this smooth landscape had currency already in Anglo-Saxon times, both in the literary and patristic traditions as confirms the presence of the motif, among others, in the Old English Phoenix (lines 20-27), Alcuin of York's Interrogationes et responsiones in Genesis, and Bede's commentary on 2 Peter 2.5. From this early dissemination of the smoothlandscape motif in England, Weber concludes, "by the time he wrote Orfeo, the poet was familiar with the "smooth paradise' simply as a popular motif not necessarily tied to its exegetical origins" (27). While the processes of popularization of concepts originated in more learned contexts may prove elusive to us, the description of fairyland as "smope \& plain," similar to the "unsmēpes" (unsmooth, rough) earthly paradise of the Old English Phoenix (26), owes much to English popular culture and was absent from any previous rendering of the story of Orpheus. It seems unlikely, therefore, that the Sir Orfeo poet borrowed this motif from his source, supposedly written in either Old French or Anglo-Norman.

\footnotetext{
"Note, however, that the ultimate source for this description is Apoc. 21.21: "platea civitatis aurum mundum, tanquam vitrum perlucidum" (the street of the city was pure gold, as it were translucent glass); cf. Putter (Introduction, 159-61).
} 
After finishing her first visit to fairyland, Heurodis receives the following instructions from the Fairy King: "Loke, dame, to-morwe patow be / Rizt here vnder pis ympe-tre" (165-66; Look, lady, that tomorrow you will be right here under this grafted tree), so that she will accompany him to the underworld realm forever. Once Orfeo is in the know, he decides to assemble his soldiers to prevent his wife's abduction. The same narrative development appears in The Wooing of Etain: first, the deferred abduction ("Come a month from to-day and that shall be given thee," 181) and next the military arrangements ("Eochaid mustered the flower of the warriors of Ireland to Tara ..., for they knew that the man of great magic power would come," 183). There is still a third point in common between The Wooing of Etain and the Middle English Sir Orfeo that some scholars have used as evidence to consider the former as a source of the latter, namely, the rash promise used to rescue the lady (cf. Bliss, liii-liv). Orfeo displays his musical skills to obtain a promise from the Fairy King: "Now aske of me what it be" (450; Now ask from me whatever you want). In The Wooing of Etain Midir and King Eochaid, before playing a game of chess, agree on a bet: "'What shall the stake be?' said Eochaid. 'The stake that either of us shall wish,' said Midir" (181). Despite the obvious similarities, the differing narrative circumstances preclude the probability of direct derivation, but instead suggest, as Bliss argues, that "at best The Wooing of Etain can be considered only as a story in which a number of Celtic motifs found in Sir Orfeo happen to reappear in combination" (liv).

There is one additional aspect of the rash promise that should be brought into consideration with regards to the story of Orpheus. Towards the end of the ninth century King Alfred produced an Old English translation of Boethius' Consolatio Philosophiae that significantly modifies the section on Orpheus and adds new narrative material. One of the passages interpolated in his translation reads, “ðā ðōhte hē ðæt hē wolde gesēcan helle godu, ond onginnan him ōleccan mid his hearpan, ond biddan pæt hī him āgēafan eft his wîf" (14.18-20; then he thought he would visit the gods of hell, and began to charm them with his harp, and asked them to give him back his wife). ${ }^{14}$ While Orfeus' request is not formally a rash promise, his ingratiating attitude towards a superior figure paves the way for creating a comparable situation from a communicative point of view. In other words, the Alfredian version may be said to contain the rash promise in embryo, so that it could become an essential ingredient of the Orfeo narrative when the motif was widely disseminated in the Middle English period.

\footnotetext{
${ }^{14}$ For an assessment of Alfred's redaction of the Orpheus story, see Severs; cf. Sisam 293-97. For biographical information, see Wormald.
} 
All the measures taken to prevent Heurodis's abduction are to no avail: "Ac zete amiddes hem ful rizt / Pe quen was oway y-tvizt, / Wip fairi forp y-nome" (191-93; But still the queen was snatched straight away from amongst them, with enchantment taken forth). This abduction is for real, in contrast to the previous one, which is presented as a dream in the romance. Now Heurodis literally vanishes before the eyes of the soldiers surrounding her, who find no way of understanding or explaining what has happened to her. The Voyage of Bran also describes how a "woman went from them, while they knew not whither she went" (16). The most basic rules that govern the physical world of mortals cannot provide a convincing explanation for what happened to Heurodis and this puzzlement leaves Orfeo downhearted. So despondent does he feel that Orfeo abandons his kingdom to find refuge in the wilderness: "In-to wildernes ichil te, / \& liue per euermore / Wip wilde bestes in holtes hore" (212-14; I will go into the wilderness and live there ever more with wild beasts in the hoar woods). The exact same reaction occurs in the Celtic tradition: when learning that Fand has left him to join Manamán, Cú Chulainn "was for a long time without drink or food, wandering through the mountains" (The Wasting Sickness of Cú Chulainn 148). But King Alfred's translation provides with an earlier testimony of greater relevance for the purpose of this paper, since it contains an interpolation showing how Orpheus retires from the world and retreats into the woods:

Đā sǣdon hī pæt ðæs hearperes wîf sceolde ācwelan ond hire sāule mon sceolde lǣdan tō helle. Đā sceolde se hearpere weorðan swā sārig pæt hē ne meahte ongemong ōorum mannum bīon, ac tēah tō wuda, ond sæt on ðǣm muntum ǣ gðer ge dæges ge nihtes. (13.9-13). ${ }^{15}$

[Then they said that the harper's wife died and her soul was supposed to go to hell. Then the harper was said to be so sad that he could not be among other people, but withdrew to the woods and stayed in the mountains both by day and by night.]

At first, Orfeo's seems a desperate and irrational decision that, however, can be understandable because he feels that reason has let him down and has offered no help in either preventing or comprehending Heurodis's disappearance. ${ }^{16}$ Though contrary to reason, Orfeo's decision is not a hasty one

\footnotetext{
${ }^{15}$ Saunders uses this reference to suggest that the author of Sir Orfeo "may also be familiar with a unique English vernacular tradition of Orpheus as seeking exile in the wilderness before his voyage to hell" (200).

${ }^{16}$ In Geoffrey of Monmouth's Vita Merlini (ca. 1150), Merlin reacts in a similar fashion when he laments the death of his heroes after the battle between the Britons and Scots, in spite of the former's victory: "Inde novas furias cum tot tantisque querelis / aera complesset cepit furtimque recedit / et fugit ad silvas nec vult fugiendo videri, / ingrediturque nemus gaudetque
} 
or one indicative of madness, since he leaves careful instructions for his nobles to prepare his succession, thus suggesting it has been thought through: " $\&$ when ze vnder-stond pat y be spent, / Make zou pan a parlement, / \& chese zou a newe king" (215-17; and when you understand that I am dead, then summon a parliament for yourselves and choose a new king for yourselves). Enjoining his nobles to summon a parliament and choose a new king manifests a particular view of the parliament, not so much as a forum for resolving judicial issues (as the English parliament did until the beginning of the fourteenth century), but instead as a legislative body with political powers, which became the parliament's new attributions after the Statute of York of 1322 (Keen 74-80). Considering that the parliament was instrumental for the deposition of Edward II on January 15, 1327 (Keen 59-61), Orfeo's stipulation resonates with topical connotations, since the poem is preserved in a manuscript that was produced ca. 1330-1340 (Pearsall and Cunningham vii). Moreover, the same manuscript contains a version of the Anonymous Short Metrical Chronicle of England (NIMEV 1105) that refers to the death of Edward II "At berkele [castle]" and closes with a prayer for "pe zong king edward" (fol. 317r). Orfeo's instructions to his nobles acquire a political dimension emanating "a very English arrangement" (Burrow and Turville-Petre 120 n.) ${ }^{17}$ and, owing to their topicality, indicate that they are attributable to the Middle English poet. In other, we have compelling evidence that Sir Orfeo, at least, is not a direct and loyal translation of its supposed Old French or Anglo-Norman source.

Orfeo's period in the woods extends for more than ten years, in really harsh conditions, until the moment the following apparation takes place:

And on a day he seize him biside

Sexti leuedis on hors ride,

Gentil \& iolif as brid on ris;

Nouzt o man amonges hem per nis. (lines 303-06)

\footnotetext{
latere sub ornis / miraturque feras pascentes gramina saltus" (lines 72-76): Then, when the air was full with these repeated loud complainings, a strange madness came upon him. He crept away and fled to the woods, unwilling that any should see his going. Into the forest he went, glad to lie hidden beneath the ash trees (trans. Clarke 56-57). This parallel reaction may have some significance for the purposes of this article, since in the same text Geoffrey of Monmouth displays his acquaintance with the story of Orpheus: "Nec curam mutabo meam uelut orpheus olim / Quando suos calathos pueris commisit habendos / Euridice stigias plus quam transnauit harenas" (lines 371-73): Nor shall I change my care as Orpheus once did when Eurydice gave her baskets to the boys to hold before she swam across the sandy Styx (trans. Clarke 70-71). The episode mentioned here, however, refers to a version of the story that is unknown to us (Clarke 139 n. and 209).
}

"See the discussion in Wade (97-98). 
[And on a day he saw next to him sixty ladies -charming and cheerful as bird on branch- riding on horses; there is not one man among them.]

Orfeo gazes at them and focuses all his attention on one, "\& sep bi al ping pat it is / His owhen quen, Dam Heurodis" (321-22; and sees by everything that it is his own queen, Lady Heurodis). This scene is reminiscent of what happens to Eochaid, in The Wooing of Etain, when he "saw fifty women all of like form and raiment as Étain" (187). This encounter is part of Midir's stratagem to thwart Eochaid's meeting with Etain. Still, we have evidence that this motif had been assimilated into English literary culture before Sir Orfeo. This evidence comes from an analogue that is chronologically and geographically closer to our romance, namely, Walter Map's De nugis curialium, composed between 1181 and 1191. One of this work's chapters tells of a Breton knight who had lost his wife and mourned her loss for a long time after having buried her, until, "in magno feminarum cetu de nocte reperit in conualle solitudinis amplissime. Miratur et metuit, et cum rediuiuam uideat quam sepelierat, non credit oculis, dubius quid a fatis agatur" (344; Dist. iv, ch. 8: He found her at night in a great company of women in a valley in a wide tract of desert. He marvelled and was afraid, and when he saw her whom he had buried, alive again, he could not trust his eyes, and doubted what the fairies (fates) could be doing; 345).

The scene of the mutual recognition of Orfeo and Heurodis is puzzling for the silence on both sides:

Zern he biheld hir, \& sche him eke,

Ac noiper to oper a word no speke;

For messais pat sche on him seize,

Pat had ben so riche \& so heize,

pe teres fel out of her eize. (lines 323-27) ${ }^{19}$

[He looked at her eagerly, and she at him too, but neither said a word to the other; the tears fell from her eye because of the wretched condition in which she saw him, who had been so rich and so exalted.]

\footnotetext{
${ }^{18}$ This episode is also mentioned in a different chapter of De nugis curialium where it is described as a case of fantasy "in quo dicitur miles quidam uxorem suam sepellisse reuera mortuam, et a chorea redibuisse raptam" (160; Dist. ii, ch. 13: in which a knight is said to have buried his wife, who was really dead, and to have recovered her by snatching her out of a dance; 161). Other conceptual confluences between the otherworld in Sir Orfeo and in Map's work are discussed by Cartlidge (203-13). While Cartlidge remarks, "De nugis curialium did not circulate widely and is unlikely to have served as a source of any kind for Sir Orfeo" (211), he also admits that "Map's work is clearly analogous to Sir Orfeo" (205). It seems quite likely, however, that De nugis curialium and Sir Orfeo were influenced by shared oral traditions. For biographical information on Map, see Brooke.

${ }^{19}$ The punctuation of this fragment follows that in Burrow and Turville-Petre (123).
} 
The two characters' speechlessness happens through enchantment, as Owen has shown, and shares some patterns with Celtic tradition. ${ }^{20}$ In The Wasting Sickness of Cú Chulainn, when he awakes from his dream, Cú Chulainn suffers temporary dumbness caused also by some enchantment: "he was not able to speak. ... he was for a year in that place without speaking to anyone at all" (31). And, once more, the same motif became available in England through Marie de France, who in her Yonec describes how the meeting of two lovers in the otherworld also involves silence, although in this case it is caused by the lady's fainting due to extreme emotion:

Si tost cum ele l'ad veü,

Le chevaler ad cuneü.

Avant alat tute esfrëe[e],

Par desus lui cheï pasmee. (lines 393-6)

[As soon as she saw the knight she recognized him, and approached in alarm, falling over him in a swoon; trans. Burgess and Busby 91]

When the effects of the enchantment wear off, Orfeo pursues these fairy ladies with the hope of gaining Heurodis back, unconcerned about the consequences for himself: "Whider-so pis leuedis ride, / pe selue way ichil streche / —Of liif no dep me no reche" (340-42; wherever these ladies may ride, I will go the same way -Whether I live or die doesn't worry me). It proves to be the right decision, since Orfeo soon follows them through a mysterious passage into the otherworld:

In at a roche pe leuedis ridep,

$\&$ he after, \& nouzt abidep.

When he was in pe roche y-go

Wele pre mile, oper mo,

He com in-to a fair cuntray. (lines 347-51)

\footnotetext{
${ }^{20}$ Broulard explains that this silence would be interpreted in the Celtic tradition as "le signe certain d'une morte-ressuscité" (111), although no supporting textual evidence is provided. Bliss (53 n. to 323-30) argues, "Orfeo and Heurodis do not speak to each other, not because of any enchantment, but because she is full of pity at the sight of his misery." Bliss imposes this interpretation on the text of Sir Orfeo by the way he punctuates the passage. However, since in the case of this poem all punctuation is editorial, the best way to ascertain the interpretation of the passage is by comparing it with other literary analogues, which in this case suggest that the speechlessness is caused by some kind of enchantment; cf. Owen. For the original punctuation of this passage in the Auchinleck manuscript, see Pearsall and Cunningham, fol. 301v, where the pause at the end of each line is marked with a punctus or punctus sine uirgula. For the interpretation of medieval punctuation, see Parkes (41-49). The manuscript can also be consulted in an electronic facsimile; see Burnley and Wiggins.
} 
[At a rock the ladies ride in and he goes after without tarrying. When he was gone in the rock three miles fully, or more, he came into a beautiful country.]

\section{Figure 1. Erlangen, Universitätsbibliothek, MS 2361, fol. 89v. Reproduced with permission}

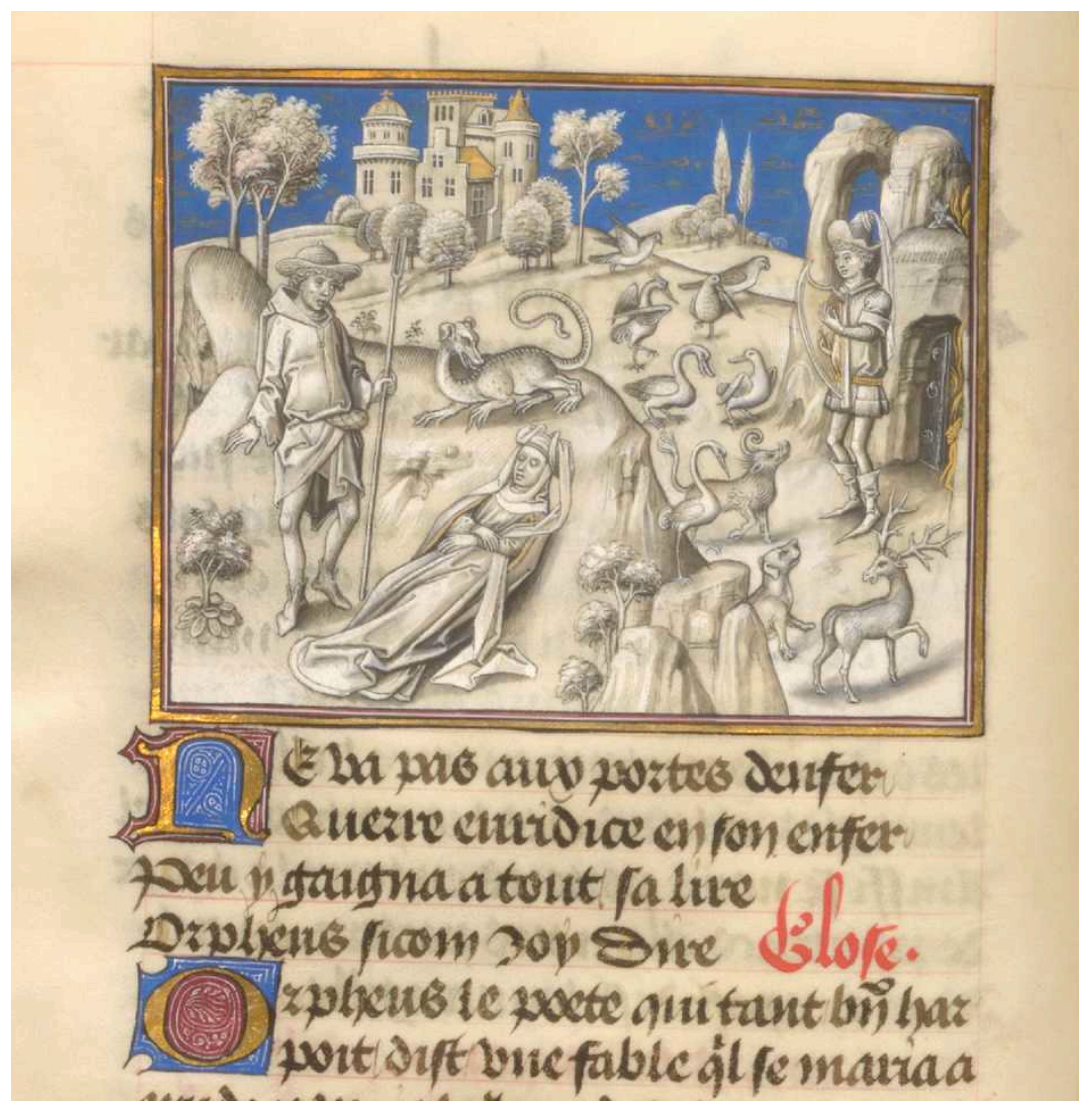

This scene must have fascinated the imagination of the poem's medieval readers and listeners, and became representative of the story as presented in this romance. So much so that a fifteenth-century manuscript of Christine de Pisan's L'Epistre d'Othea, now held in Erlangen University Library, contains an illustration that portrays Orfeo playing the harp before a gated hole in a rock, which presumably is the portal to the underworld. ${ }^{21}$ While this representation

\footnotetext{
"See fig. 1. The illustration is the work of the Flemish artist Willem Vrelant. For a description of the manuscript, see Lutze (235-46, with specific reference to this image on p. 243); for an edition of this manuscript, see Lengenfelder. I want to express my gratitude to Elisabeth Engl
} 
gives us a sense of the attraction this moment exerted among late medieval audiences, the belief that the otherworld could be accessed through a rock has an earlier origin. In the corpus of Celtic literature I have been unable to identify otherworld entrances through a rock, although according to Celtic lore there exist passages communicating the two worlds (Broulard 54). ${ }^{22}$ By contrast, the same motif is present in a text with English circulation, namely, Marie de France's Yonec, where the lady follows her lover to the underworld across a hill:

En cele hoge ot une entree,

De cel sanc fu tute arusee;

Ne pot nient avant veer.

Dunc quidot ele bien saver

Que sis amis entré i seit;

Dedenz se met en grant espleit. (lines 347-52)

[In this hill there was an opening, all covered in his blood, but she could see nothing beyond and therefore assumed that her beloved had entered there. She hurriedly went in; trans. Burgess and Busby 90]

The lady returns through the same passageway: "Vers la hoge sa veie tient; / Dedenz entra, si est passee, / Si s'en reveit en sa cuntree" (450-52; [she] made her way towards the hill, which she passed through and arrived back in her own region; trans. Burgess and Busby 92). As in the case of Sir Orfeo, it is a two-way passage that is later used to return back to the normal world. Another English text, though somewhat later, also refers to the same tradition of using a rock as a portal into the otherworld. It is the Middle English romance The Turke and Gawin (NIMEV 1886), which reads, "He [i.e. the Turk] led Sir Gawaine to a hill soe plaine; / the earth opened \& closed againe" $(66-67){ }^{23}$

After entering the otherworld and gaining access to the Fairy King's castle, Orfeo contemplates a scene of Dantesque nature:

ban he gan bihold about al

\& seize liggeand wip-in pe wal

Of folk pat were pider y-brouzt,

$\&$ pouzt dede, \& nare nouzt.

for making arrangements for my consulting this manuscript, and to the staff of Erlangen University Library for their kind assistance and granting permission to reproduce this image.

${ }^{n}$ This belief is not unique to Celtic mythology, but appears in Norse mythology as well, since we see how the domain of Hel is accessed through an opening named Gnipahellir or "cliffcave" (Gordon 202 n. 457).

"Although the text is preserved in the so-called Percy Folio manuscript (British Library, Additional 27879, pp. 38-46), produced ca. 1650, the poem was composed towards the end of the fifteenth century. For a discussion of the manuscript, see Rogers. 
Sum stode wip-outen hade,

$\&$ sum non armes nade,

$\&$ sum purth pe bodi hadde wounde,

$\&$ sum lay wode, y-bounde,

$\&$ sum armed on hors sete,

$\&$ sum astrangled as pai ete;

$\&$ sum were in water adreynt,

$\&$ sum wip fire al for-schreynt.

Wiues per lay on child-bedde,

Sum ded \& sum awedde. (lines 387-400) ${ }^{24}$

[Then he looked at everything around and saw people lying within the wall that were brought there and were thought to be dead, but were not. Some stood without head, and some had no arms, and some had a wound through the body, and some lay bound mad, and some sat armed on horses, and some choked as they ate, and some were drowned in water, and some completely scorched to death with fire. Women lay there on childbed, some dead and some mad.]

Taken by this graphic description, Bruce Mitchell has argued, "the original of these offending passages was not in the first instance part of the poem" (158), alleging a supposed inconsistency. In his previous apparition, however, when the Fairy King summons her to meet him the following day, he already utters a dire threat of violence:

\& zif pou makest ous y-let,

Whar pou be, pou worst y-fet,

$\&$ to-tore pine limes al,

\footnotetext{
${ }^{24}$ Knapp comments that the underworld "is a place filled with people who have died in suffering, or violence, or madness" (267). The underworld dwellers in Sir Orfeo, however, "were pider y-brouzt, / \& pouzt dede, \& nare nouzt" (389-90), that is, they are not necessarily dead, although they may seem to be. Allen accurately interprets these lines with reference to Celtic superstition, according to which certain types of death were explained by the intervention of the fairies, who would take the deceased to the otherworld. In these circumstances they were not considered dead, but taken, a belief that corresponds closely with our version. Brouland has proposed a complementary reading. In her view, the people Orfeo encounters "semblant être une réinterpretation nouvelle d'un thème populaire de la tradition celtique, celui des morts multiples" (212). Multiple death consists in the combination of different and opposite elements which cause the triple death of a person. In his Vita Merlini Geoffrey of Monmouth describes how Merlin predicts the triple death of a youth: "hic morietur homo de celsa rupe ruendo" ( 311 ; this lad will die by falling from a high rock; trans. Clarke 68-69); "Puer hic cum venerit etas / mente vagans forti succumbet in arbore morti" (320-21; When this boy grows up, he will meet a violent death in a tree through misjudgment; trans. Clarke 68-69), and finally "morietur in ampne" (338; he will die in a river; trans. Clarke 6869). See also Saunders 203-04.
} 
Pat noping help pe no schal;

$\&$ pei pou best so to-torn,

Zete pou worst wip ous y-born. (lines 169-74)

[And if you offer us resistance, wherever you may be, you will be fetched and all your limbs torn to pieces, so that nothing shall help you; and although you will be thus torn to pieces, still you will be carried off with us.]

These words alert us vividly to the King's cruelty and, therefore, prepare us for the living conditions that Orfeo finds in the otherworld castle. Although this incident is unique to our version, it shows a certain level of affinity with the Alfredian rendering which, departing from the classical account, refers to the dwellers of hell and their suffering: "ond eall hellwara wìtu gestildon, ðā hwīle pe hē beforan ðām cyninge hearpode" (14.41-42; and all the inhabitants of hell rested from their torments, while he harped before the king). It seems plausible that this component of cruelty, although amplified by the Middle English poet, was already an ingredient part of the insular tradition of the Orfeo story.

This article shows that the story of Orpheus circulated in England at least from the times of King Alfred, whose translation of Boethius departs significantly from the classical account. Regarding the otherworldly experiences and descriptions in the Middle English romance, while the influence of a Celtic substratum seems apparent, none of the texts of Celtic origin mentioned in this article was used as a direct source by the English poet. Instead, the motifs they contain had already been assimilated and naturalized into English popular culture by the time the Middle English poem was composed, as the description of Fairyland shows. By contrast, King Alfred's alterations to the classical version, in particular those affecting the otherworld, are coherent with and find continuity in the Middle English romance because of the existence of a rich oral tradition. As Wade suggests, "the Orfeo story probably picked up resonances not only through its classical antecedents, but also through other similar Otherworld accounts circulating in chronicles and miracle stories, and, presumably, in oral tradition as well" (80). Unfortunately, oral phenomena leave little if any trace in the more learned, written culture. It seems likely that there existed an insular tradition of the history of Orpheus, as the allusion in Geoffrey of Monmouth's Vita Merlini implies (cf. n. 14), that was gradually expanded and altered by the introduction of otherworldly features as they became more accessible in England, especially after Marie de France's Breton lays.

Considering that neither the variations introduced by King Alfred nor the insular tradition mentioned by Geoffrey of Monmouth circulated on the continent, it cannot be assumed that they informed the Old French lai d'Orphey 
mentioned in other medieval French texts. Still, we cannot exclude the possibility that the Middle English poet could have used an Old French version and adapted it to the insular tradition. The Middle English text as preserved in the Auchinleck manuscript, however, cannot be considered an exact translation of a French version, since it contains elements of topicality meant for the text's English audience. What is more, since the romance text presents clear signs of memorial transmission, ${ }^{25}$ it seems more reasonable to assume that it was influenced by the oral tradition that articulated the insular form of the classical narrative. In addition, the conspicuous absence of a lay of Orfeo in the Shrewsbury manuscript is a strong indication that no Anglo-Norman version of the story circulated widely across England during the thirteenth century. Consequently, Bliss's hypothesis that the Middle English Sir Orfeo is based on an Anglo-Norman or Old French version should be reconsidered. Sir Orfeo could actually represent the most complete textual witness of the insular tradition of the Orpheus story, which goes back to Anglo-Saxon times and evolved as it was disseminated orally incorporating influences from the genre of the Breton lays. Rather than accepting the existence of a hypothetical source, of whose existence we have serious doubts and of whose influence we have no sufficient evidence, some scholarly consideration should be given to the theory offered in this paper, although it is here proposed with caution as a conjectural possibility.

\section{WORKS CITED}

The Adventure of Cian's Son Teigue. Ed. Standish H. O'Grady. Silva Gadelica. Vol. 2: 385-401. London, 1832-1915. 31 vols.

Allen, Dorena. "Orpheus and Orfeo: The Dead and the Taken." Medium AEvum 33 (1964): 102-11. https://doi.org/10.2307/43627090

Archibald, Elizabeth. "The Breton Lay in Middle English: Genre, Transmission and the Franklin's Tale." Medieval Insular Romance: Translation and Innovation. Eds. Judith Weiss, Jennifer Fellows and Morgan Dickson. Cambridge: D. S. Brewer, 2000. 55-70.

Bennett, J. A. W. Middle English Literature. Ed. Douglas Gray. Oxford: Clarendon Press, 1986.

Biblia Sacra Juxta Vulgatam Clementinam. Rome: Desclée, 1956.

Bliss, J. A. ed. Sir Orfeo. 2nd ed. Oxford: Clarendon Press, 1966.

\footnotetext{
${ }^{2}$ Putter ("Historical Introduction," 33 n. 22).
} 
Boethius. Consolatio Philosophiae. Corpus Scriptorum Ecclesiasticorum Latinorum 67. Ed. W. Weinberger. Vienna: Hoelder-Pichler-Tempsky, 1934.

Brereton, Georgine E. "A Thirteenth-Century List of French Lays and Other Narrative Poems." Modern Language Review 45 (1950): 40-45. https://doi.org/10.2307/3719658

Brooke, C. N. L. "Map, Walter (d. 1209/10)." Matthew and Harrison 36. 57779.

Brouland, Marie-Thérèse. Sir Orfeo: Le substrat celtique du lai breton anglais. Paris: Didier, 1990.

Burgess, Glyn S., and Keith Busby. Trans. The Lais of Marie de France. 2nd ed. London: Penguin, 1999.

Burnley, David and Alison Wiggins. The Auchinleck Manuscript. National Library of Scotland, 2003. Web. 10 May 2017. $<$ http://auchinleck.nls.uk>.

Burrow, J. A. and Thorlac Turville-Petre. A Book of Middle English. 2nd ed. Oxford: Blackwell, 1996.

Cartlidge, Neil. "Sir Orfeo in the Otherworld: Courting Chaos?" Studies in the Age of Chaucer 26 (2004): 195-226. https://doi.org/10.1353/sac.2004.0038

Chestre, Thomas. Syr Launfal. Of Love and Chivalry: An Anthology of Middle English Romance. Ed. Jennifer Fellows. Everyman's Library. London: Dent, 1993. 199-229.

Crick, J. C. "Monmouth, Geoffrey of (d. 1154/5)." Matthew and Harrison 38. 629-32.

Friedman, John B. Orpheus in the Middle Ages. Cambridge: Harvard University Press, 1970.

Gordon, E. V. An Introduction to Old Norse. 2nd ed. Rev. A. R. Taylor. Oxford: Clarendon Press, 1957.

Gray, Douglas. "Chestre, Thomas (fl. late 14th-early 15th cent.)." Matthew and Harrison 11. 353.

Hunt, Tony. "Marie (fl. c.1180-c.1189)." Matthew and Harrison 36. 666.

Jirsa, Curtis R. H. "In the Shadow of the Ympe-tre: Arboreal Folklore in Sir Orfeo." English Studies $89 \quad$ (2008): 141-51. https://doi.org/10.1080/00138380801912909

Keen, Maurice. England in the Later Middle Ages: A Political History. 2nd ed. London: Routledge, 2003. 
Ker, N. R. and A. J. Piper. Medieval Manuscripts in British Libraries. Vol. 4. Oxford: Clarendon Press, 1992. 5 vols. 1969-2002.

Kittredge, George L. "Sir Orfeo.” American Journal of Philology 7 (1886): 177202. https://doi.org/10.2307/287332

King Alfred. "From King Alfred's Translation of Boethius." Sweet's AngloSaxon Reader in Prose and Verse. Rev. Dorothy Whitelock. Oxford: Clarendon Press, 1970. 8-16.

Knapp, James F. "The Meaning of Sir Orfeo." Modern Language Quaterly 29 (1968): 263-73. https://doi.org/10.1215/00267929-29-3-263

Lengenfelder, Helga, ed. Christine de Pizan, L'Epistre d'Othéa: FarbmikroficheEdition der Handschrift Erlangen-Nürnberg, Universitätsbibliothek, Ms. 2361. Codices illuminati medii aevi 31. Munich: Editions Helga Lengenfelder, 1996.

Loomis, Roger Sherman. Celtic Myth and Arthurian Romance. 1926. London: Constable, 1995.

Lutze, Eberhard. Die Bilderhandschriften der Universitätsbibliothek Erlangen. Wiesbaden: Otto Harrassowitz, 1971.

Map, Walter. De nugis curialium: Courtiers' Trifles. Ed. and trans. M. R. James, rev. C. N. L. Brooke and R. A. B. Mynors. Oxford: Clarendon Press, 1983.

Marie de France. Lais. Ed. Alfred Ewert. Blackwell's French Texts. Oxford: Blackwell, 1965.

Marvin, William P. "Chronological Outline of Historical Events and Texts in Britain, 1050-1550." The Cambridge History of Medieval English Literature. Ed. David Wallace. Cambridge: Cambridge University Press, 2002. 852-80.

Matthew, H. C. G. and Brian Harrison. Eds. Oxford Dictionary of National Biography. Oxford: Oxford University Press, 2004. 61 vols.

Mitchell, Bruce. "The Faery World of Sir Orfeo." Neophilologus 48 (1964): 155-59. https://doi.org/10.1007/BF01515535

Monmouth, Geoffrey of. Life of Merlin: Vita Merlini. Ed. and trans. Basil Clarke. Cardiff: University of Wales Press, 1973.

Julia Boffey and A. S. G. Edwards. A New Index of Middle English Verse. London: The British Library, 2005.

Ovid. Metamorphoses. Trans. Frank Justus Miller. 3rd ed. Rev. G. P. Goold. Loeb Classical Library. Cambridge, MA: Harvard University Press, 1984. 2 vols. 
Owen, Lewis J. "The Recognition Scene in Sir Orfeo." Medium Avum 40 (1971): 249-53. https://doi.org/10.2307/43627748

Parkes, M. B. Pause and Effect: An Introduction to the History of Punctuation in the West. Aldershot: Ashgate, 1992.

Patch, Howard R. "Some Elements in Mediæval Descriptions of the Otherworld." Publications of the Modern Language Association 33 (1918): 601-43. https://doi.org/10.2307/456983

---. The Other World according to Descriptions in Medieval Literature. Cambridge: Harvard University Press, 1950.

Pearl. The Works of the Gawain Poet: Sir Gawain and the Green Knight, Pearl, Cleanness, Patience. Eds. Ad Putter and Myra Stokes. London: Penguin, 2014. 2014: 3-81.

Pearsall, Derek, and I. C. Cunningham. Eds. The Auchinleck Manuscript: National Library of Scotland, Advocates' MS. 19.2.1. London: Scolar Press, 1979.

The Phoenix. Ed. N. F. Blake. Old and Middle English Texts. Manchester: Manchester University Press, 1964.

Purdie, Rhiannon, ed. Shorter Scottish Medieval Romances: Florimond of Albany, Sir Colling the Knycht, King Orphius, Roswall and Lillian. Scottish Text Society. Woodbridge: Boydell Press, 2013.

Putter, Ad. “A Historical Introduction.” The Spirit of Medieval English Popular Romance. Eds. Ad Putter and Jane Gilbert. Harlow: Longman, 2000. 1$15,31-34$.

---. An Introduction to the Gawain-Poet. London: Longman, 1996.

---. and Jane Gilbert. Eds. The Spirit of Medieval English Popular Romance. Harlow: Longman, 2000.

---. and Myra Stokes. Eds. The Works of the Gawain Poet: Sir Gawain and the Green Knight, Pearl, Cleanness, Patience. London: Penguin, 2014.

Rogers, G. "The Percy Folio Manuscript Revisited." Romance in Medieval England. Ed. Maldwin Mills, Jennifer Fellows and Carol Meale. Cambridge: D. S. Brewer, 1991. 39-64.

Saunders, Corinne. "Magic and the Supernatural in Medieval English Romance". Studies in Medieval Romance 13. Cambridge: D. S. Brewer, 2010.

Severs, J. Burke. "The Antecedents of Sir Orfeo." Studies in Medieval Literature in Honor of Professor Albert Croll Baugh. Ed. MacEdward Leach. Philadelphia: University of Pennsylvania Press, 1961. 187-207. https://doi.org/10.9783/9781512817508-012 
Seymour, M. C. "Bartholomaeus Anglicus (b. before 1203, d. 1272)." Matthew and Harrison 4. 161-62.

Sisam, Kenneth. Studies in the History of Old English Literature. Oxford: Clarendon Press, 1962.

Sir Gawain and the Green Knight. The Works of the Gawain Poet: Sir Gawain and the Green Knight, Pearl, Cleanness, Patience. Eds. Ad Putter and Myra Stokes. London: Penguin, 2014. 237-406.

Sir Orfeo. Ed. A. J. Bliss. 2nd ed. Oxford: Clarendon Press, 1966.

Smithers, G. V. "Story Patterns in Some Breton Lays." Medium AEvum 22 (1953): 61-92. https://doi.org/10.2307/43626509

Spearing, A. C. “Sir Orfeo: Madness and Gender.” Putter and Gilbert. 258-72.

Stokes, Myra. "Lanval to Sir Launfal: A Story Becomes Popular." Putter and Gilbert. 56-77.

The Turk and Gowin. Bishop Percy's Folio Manuscript: Ballads and Romances. Ed. John W. Hales and Frederick J. Furnivall. Vol. 1: 90-102. London, 1867-1868. 4 vols.

Virgil. Georgicon. P. Vergili Maronis Opera. Ed. R. A. B. Mynors. Oxford: Clarendon Press, 1969.

The Voyage of Bran Son of Febal. Ed. and trans. Kuno Meyer. London, 189597.2 vols.

The Voyage of Mael Duin. Ed. and trans. Whitley Stokes. Revue Celtique 9 (1888): 447-95; 10 (1889): 50-95.

The Voyage of the Húi Corra. Ed. and trans. Whitley Stokes. Revue Celtique 14 (1893): 22-69.

Wade, James. Fairies in Medieval Romance. New York: Palgrave Macmillan, 2011. https://doi.org/10.1057/9780230119154

The Wasting Sickness of Cú Chulainn (Trans. of Sergigle Con Culainn). Ed. and trans. Myles Dillon. Columbus: Hendrick, 1941.

Weber, Ben. "Smothe and Plain and Al Grene': Sir Orfeo's Flat Fairyland." Notes and Queries, n. s., 58 (2011): 24-28.

The Wooing of Etain (Trans. of Tochmarc Etaine). Ed. Osborn Bergin. Trans. Eleanor Knott. Ériu 12 (1938): 142-93.

Wormald, Patrick. “Alfred (848/9-899).” Matthew and Harrison 1. 716-25. 